\title{
心理生理指標による職務充実に関する研究*
}

中塚 信宏 ${ }^{* 1}$, 朴 美卿 ${ }^{* 2}$, 滝 聖子 ${ }^{* 3}$, 山中 仁寛 ${ }^{* 3}$, 川上 満幸 ${ }^{* 1}$

\section{A Study on Job Enrichment Using Psychophysiological Parameters}

\author{
Nobuhiro NAKATSUKA, Mi Kyong PARK, Seiko TAKI, Kimihiro YAMANAKA*3 \\ and Mitsuyuki KAWAKAMI \\ ${ }^{* 3}$ Department of Management Systems Engineering, Tokyo Metropolitan University \\ 6-6 Asahigaoka, Hino, Tokyo, 191-0065 Japan
}

The aim of this study was to examine the effect of job enrichment system in terms of brain activation by measuring EEG. Ten male students participated in both a assembly work of Lego blocks without any feedback information (No-feedback task) and a job enrichment which receives feedback information for the work progress and the faults in the assembly work (Feedback task). We measured EEG, ECG, Jikaku-sho Shirabe, NASA-TLX, and morale survey. The results were as follows: (1) In Feedback task, productivity was significantly boosted by increasing worker morale such as fun, enthusiasm, and sense of fulfillment and accomplishment. (2) Subjective ratings of dullness, boredom, frustration was significantly lower in Feedback task than in No-feedback task. (3) Heart rate significantly increased in Feedback task compared with in No-feedback task. (4) Alpha1 $(8-10 \mathrm{~Hz})$ and alpha $2(10-13 \mathrm{~Hz})$ waves related with sense of fun, fulfillment, and accomplishment in frontal and central areas increased in Feedback task compared with in No-feedback task. The results suggest that the job enrichment with feedback information had a positive effect on workers, and the effectiveness of job enrichment system was demonstrated by measuring of psychological parameters including EEG.

Key Words : Job Enrichment, EEG, Heart Rate, NASA-TLX, Morale Survey

\section{1. 緒言}

テーラーの科学的管理法が提唱されて以来, 生産現場では, 動作分析により作業方法の標準化, 分業, 専門化 が行われた ${ }^{(1)(2)}$. 作業の質的分業を行う事で, 自動車会社のフォードはコンベアラインによる流れ生産方式を確立 し，低コストで大量生産を行うことが可能となった。しかし，ベルトコンベアにより作業者は単純繰り返し作業 を強いられ，自主性や自由性を抑えられ人間疎外という現象を引き起こした ${ }^{(3)}$.ところが，1924 年からメイヨー が行ったホーソン実験により作業者のモチベーションが生産性に影響していることが判明し，マグレガーの XY 理論や Herzberg の動機づけ理論など作業者の人間性も研究対象となっている. Herzberg ${ }^{(4)}$ は職務を行う人間はど のような要因で動機付けられるかを調査し, 達成, 承認, 責任, 仕事自体といった職務内容と直接関係のある要 因が動機付け可能な要因とした. しかし，この動機付け理論には，欧米と日本の文化の違いや対象にした標本に ブルー・カラーが少ないなど批判があったが，杉村ら ${ }^{(5)}$ (8) は，これら批判を踏まえ調査を行ったところ，達成， 成長，責任の各因子は人を職務に動機づけ可能な満足要因であると結論付けた．作業者は，動機付けられていな

* 原稿受付 2012 年 3 月 8 日

*1 首都大学東京 システムデザイン研究科

*2 首都大学東京 システムデザイン学部

*3 正員, 首都大学東京 システムデザイン研究科（テ191-0065 東京都日野市旭が丘 6-6）

E-mail: kiyamana@sd.tmu.ac.jp 
いかつ不満が高い状態で職務を行っていると, 職務放棄や離職といった問題を引き起こすことがある.そのため, 質的分業を中心とした古典的 IE（Industrial Engineering）に人間性に関する理論を調和させ，生産性と人間性が調 和した生産形態の構築が重要である。

生産性と人間性が調和した生産形態としては職務拡大，職務充実といった職務再設計が挙げられる．職務拡大 は作業者の課業を増やし単調感を減らすこと（量的分業）である．職務充実は，仕事に責任や権限を与え，拘束 感を減らし作業者自身が PDCA サイクルを回せる職務設計の考え方で, 達成感, 責任といった Herzberg の動機付 け要因のほとんどを網羅している，職務再設計は生産現場の実験において，生産性や意識調査，フリッカー検査 から有效性が実証されている，例えば，川上ら ${ }^{(9)}$ は，職務拡大する事により生産性，作業意識の向上，フリッカ 一值が維持し作業負担が小さいと報告している. また, 動作分析により, 職務拡大された作業では取置作業に付 随する仕掛品の位置決めなどが減ることも生産性向上に貢献した ${ }^{(10)} と$ 報告している.

職務充実では，西野ら ${ }^{(11)}$ は，作業に遊び的要因である意味性や自己統制を加え，作業成績をフィードバックし た際に，作業者はポジティブな感情が高まったと報告し，内的目的性という要因が仕事の設計において中核次元 であるとしている，また，矢田ら ${ }^{(12)}$ は, QC サークルが職班長に次いで成果の結果確認, 処置に参画していると いう調查結果から，現業部門の管理方式として職務充実の要因を含む自主管理システムが有効であるとしたそそ して，その実現のためには小集団活動の発展的育成が必要であると報告している. 人間は参画する事でモチベー ションが上がると言われている(13). しかし，自主管理システムにより労務負担が増え，労働強化と受け取られる 恐れがあるため, 現業部門の管理を簡素化する必要があるとも指摘している ${ }^{(14)}$. 長町 ${ }^{(15)}$ は QC サークルや ZD 運 動といった小集団活動の活性化は生産性とモチベーションを向上させるとし, 小集団の活性化診断手法を報告し ている.

しかし，このような先行研究では，作業者の主観調査が多く，一部フリッカー検査が用いられているが，脳波 や心電図といった生理計測と合わせた報告は少ない，近年，脳波を作業者の満足度の推定に用いた研究(16)や，大 脳皮質一扁桃核間の神経回路が働くことによって報酬系, 動機付けなどの形成がなされるという報告がある ${ }^{(17)}$. また，情動を司る扁桃核から大脳皮質前頭葉へ神経線維連絡があることから，情動にとって前頭葉は大変重要な 部位であると指摘されるなど(18)，モチベーションや情動の研究に人の脳活動を測定する試みが多くなされている. もし, 職務充実を取り入れ, 動機付けられた時の作業者の生理特性が脳波で明らかになれば, 職務充実作業の効 果を客観的に裏付けることができると考えられる.

そこで，本研究では職務充実を取り入れていない通常作業と職務充実作業の 2 つ生産形態において, 脳波計 測により脳内活動領野の観点から職務充実の効果を考察することを目的とする.

\section{2. 実験方法}

\section{$2 \cdot 1$ 実験環境及び被験者}

実験は室度 $25^{\circ} \mathrm{C}$, 相対湿度 50\%の恒温恒湿シールドルーム(シールドルーム株式会社, SAD-0001, 縦 2535×横 2540x奥行 $3240 \mathrm{~mm}$ ) 内で行った. 作業台の照度は JIS-Z9110の 5 点法により 7501x である事を確認した. 被験 者は心電図, 脳波それぞれに異常のない $21 ２ 5$ 歳の男子学生 10 名（平均年齢 23 才 $\pm 1.49 ）$ とした. また, 被験 者には事前に実験に関する十分な説明を行い，書面にて同意を得た後実験を実施した.

\section{$2 \cdot 2$ 実験条件}

実験で扱う作業課題は，レゴブロック（LEGO 8304 スモーキン・スリックスター）を用いた車の組立作業と した. 標準時間の算出は, 川上が提唱している回帰式を使用した ${ }^{(19)}$.これは組立部品の種類数と点数に着目し, 適正作業量を算出するもので，組立に要する作業時間を MTM 法で算出した正味作業時間（TN）に対する実遂行 時間（TA）の比 $(\mathrm{TA} / \mathrm{TN})$ とした時, $\mathrm{Y}(=\mathrm{TA} / \mathrm{TN})=0.32 \mathrm{X}+78.1 \pm 9.4$ で表わされる. この式を利用し，作業時 間比が 100\%を超える事は生産計画上において望ましくないという考えから，上側信頼限界である $\mathrm{Y}=0.32 \mathrm{X}+$ 87.5 を取り, かつ余裕率 $15 \%$ 含め、組立時間が約 90 秒になる様に部品点数, 種類数を調整した. そして算出 した標準時間を参考に総作業時間が 50 分前後になるように組立台数は 28 台とした.

実験条件は，通常作業（以下，作業情報無と表記）と作業進行度, 不良情報を被験者にフィードバックするこ 
とで職務充実を図った職務充実作業（以下，作業情報有と表記）の 2 条件とした。作業進行度はパワーポイント のアニメーション機能を使用し，作業者の前方に設置したモニターから呈示した．また，不良情報は，音声によ り被験者にフィードバックした．被験者は作業情報無と作業情報有の両方の実験に参加した．被験者には習熟に よる影響を考慮し，事前に十分な習熟を行ってもらい，順序効果による影響を排除するため 2 種類の作業条件を ランダムな順序で割り当てた。 まず， 1 回目の実験が終わった後，十分な安静をとり被験者に疲労がないことを 確認した上，次の実験を行った。 図 1 に作業場レイアウトを示す.

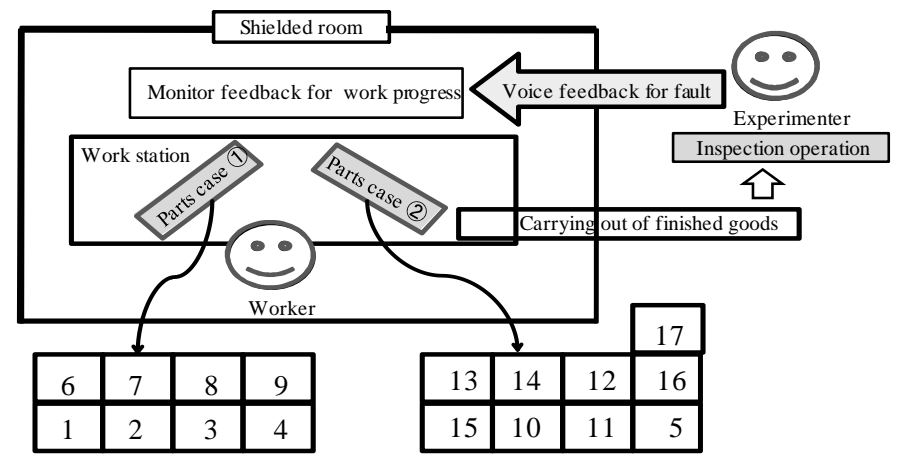

Fig. 1 Workplace layout

\section{$2 \cdot 3$ 測定項目}

組立作業時間を算出寸る為に，ハイスピードカメラ（H-1600-M2）を使用し，20 コマ/秒で作業を録画した. 心理指標は, 日本産業衛生学会産業疲労研究会で作成された25項目からなる自覚症しらべと日本語版NASATLXに加え, NRK（日本労務研究会），THI（Total Health Index）などのモラール・サーベイを参考に自作したア ンケートとした.メンタルワークロードを測定するために用いたNASA一TLXは, 精神的要求 (mental demand: MD), 身体的要求 (physical demand: PD), 時間的圧迫感（temporal demand: TD）, 作業達成度 (performance: $\mathrm{OP}$ ), 努力

(effort: EF) 及び不満（frustration: FR）の6項目の評価尺度から構成されている. 本研究では，それぞれの尺度の 評価值の大きい順に6，5，4，3，2，1の重みを付けて求める適応加重平均作業負荷得点（Adaptive mean Weighted WorkLoad score: AWWL得点）をメンタルワークロードの評価指標とした ${ }^{(20)}$.

生理指標としては心電図, 脳波の計測を行った。心電図の計測は胸部 2 点間の電位差を求める双極誘導により 行い，導出した心電図はマルチテレメータシステム（日本光電, ZR-581G）により増幅後, サンプリング周波数 $200 \mathrm{~Hz}$ でデータレコーダー（TEAC，AQ-VU）に記録した。心電図の解析では，信号処理解析ソフト（キッセイ コムテック, BIMTUS II ) により, 空関数にハミング空を適応して FFT ポイント数 4096 で高速フーリエ変換 (FFT) を行った. 得られたパワースペクトルは， $0.05 \sim 0.15 \mathrm{~Hz}$ の区間を積分したものを心拍変動の LF 成分とし， 0.15 $\sim 0.45 \mathrm{~Hz}$ の区間を積分したものを心拍変動の HF 成分とした．また，LF 值，HF 值から LF/HF 值を算出し，心拍 数は R-R 間隔から算出した.

脳波は，両耳染を基準電極とし，国際 10/20 法に従い，Fp1，Fp2，F3，F4，F7，F8，C3，C4，P3，P4，T5， T6， Fz，Cz，Pzの 15 部位より導出した。同時に瞬目によるアーティファクト除去の為，右眼窩下縁部に電極を 装着し眼球電図を計測した，導出した信号は，脳波計測用電極箱（NEC 三栄，6R12-4）を介し，Low-Cutフィル タは $1.6 \mathrm{~Hz}$ ，High-Cutフィルタは $60 \mathrm{~Hz}$ に設定した生体信号アンプ（NEC，BIOTOP 6R12）で増幅した。増幅した 信号は，サンプリング周波数 $200 \mathrm{~Hz}$ でデータレコーダー（AV-LX 100EPIO EXPAND I/O BOX）を介し PC に記録 した．脳波は，心電図と同様の解析ソフトを使用し，瞬目によるアーティファクトの除去後，FFT による周波数 分析を施した. 周波数分析は空関数ハミングとし，評価に用いる周波数帯域は $\theta$ 波 ( $4 \sim 8 \mathrm{~Hz}$ 未満), $\alpha 1$ 波（8〜 $10 \mathrm{~Hz}$ 未満)， $\alpha 2$ 波 (10 $13 \mathrm{~Hz}$ 未満)， $\beta 1$ 波 (13 $20 \mathrm{~Hz}$ 未満)， $\beta 2$ 波 $(20 \sim 30 \mathrm{~Hz}$ 未満）の 5 帯域とし，測定部位 ごとに含有率を求めた。なお，生理指標の解析区間は， 1 台目から 4 台目の組立中を 1 期，9台目から 12 台目を 2 期，17 台目から 20 台目を 3 期， 25 台目から 28 台目を 4 期とした。表 1 に実験手順を示す。なお，作業前後の 脳波は閉眼状態で測定した. 
Table 1 Experimental procedure

\begin{tabular}{|c|c|c|c|}
\hline Index time & Pre (5min) & Assembly work (28 units) & Post (5min) \\
\hline EEG & & & $\rightarrow$ \\
\hline ECG & & & \\
\hline Morale survey & & & \\
\hline NASA-TLX & & & \\
\hline Jikaku-sho Shirabe & 0 & & \\
\hline High speed camera & & & \\
\hline
\end{tabular}

\section{$2 \cdot 4$ 統計処理}

作業前後の閉眼安静時の脳波と自覚症しらべ，NASA-TLX，モラール・サーベイ，組立にかかったサイクルタ イムの統計処理には, 対応ある $\mathrm{t}$ 検定を行った. また, 不良数はノンパラメトリック検定の Wilcoxon の符号付き 順位検定を行った。 心電図は，作業条件（作業情報無，作業情報有）と期間（前安静， 1 期， 2 期，3 期， 4 期, 後安静）を要因とした 2 元配置分散分析を，作業中の脳波は作業条件（作業情報無，作業情報有）と期間（1 期， 2 期， 3 期，4 期）を要因とした 2 元配置分散分析を行った（SPSS（株), PASW Statisyics17.0). そして, 統計的 有意判定は危険率 5\%以下の場合を有意であると判定した.

\section{3. 実験結果}

\section{$3 \cdot 1$ 生産性}

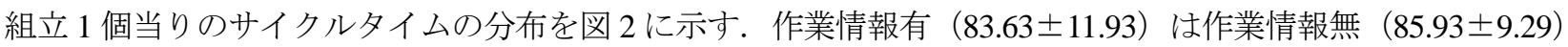
に比べてサイクルタイムが有意に短かった（p<0.01）。しかし，不良数においては作業条件間に有意差は認められ なかった。

\section{$3 \cdot 2$ 心理指標}

図 3 に自覚症しらべの結果を示寸だるさの項目においては，作業情報有が作業情報無に比べて有意に低い值 を示した。他の項目においては作業条件間に有意差は確認できなかった. 図 4 と図 5 に作業後の NASA-TLX と モラール・サーベイの結果をそれぞれ示す. NASA-TLX の総合得点である AWWL スコアでは有意差が認められ なかったものの，時間圧迫感は作業情報有が作業情報無より有意に高く，不満は作業情報有の方が有意に低かっ た。 また，モラール・サーベイにおいては，作業情報有は作業情報無と比べて楽しい, 熱中, 充実感, 能力発揮 感が有意に高く, 退屈感が有意に低かった.

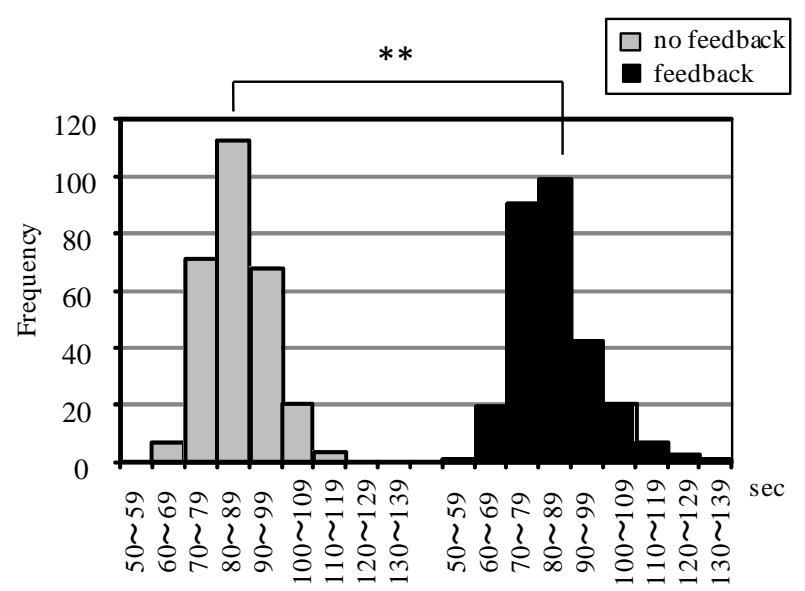

Fig. 2 Cycle time distribution during assembly work with and without feedback information $(* * \quad p<0.01)$.

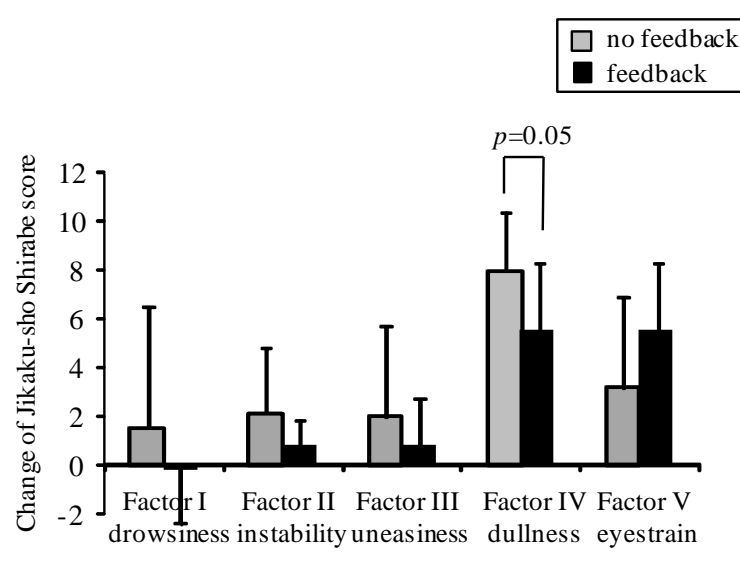

Fig. 3 Changes of Jikaku-sho Shirabe score during assembly work with and without feedback information (mean value $\pm \mathrm{SD}$ ). 


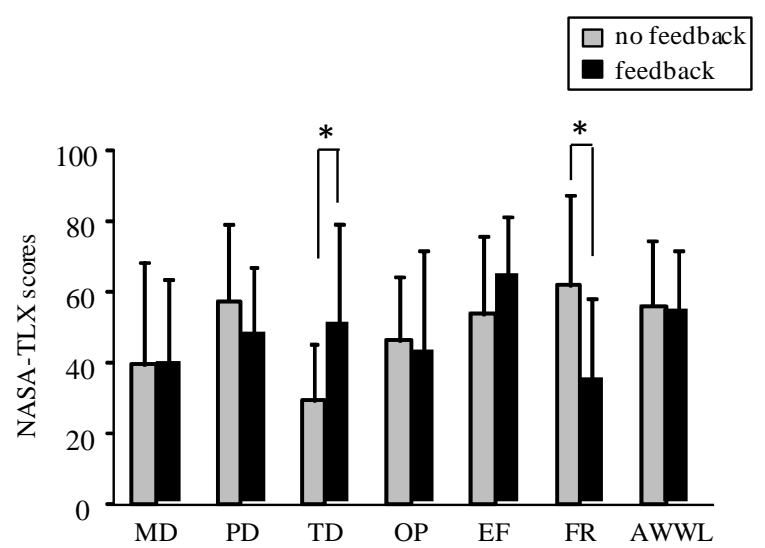

Fig. 4 NASA-TLX scores during assembly work with and without feedback information (mean value $\pm \mathrm{SD}, * p<0.05$ )

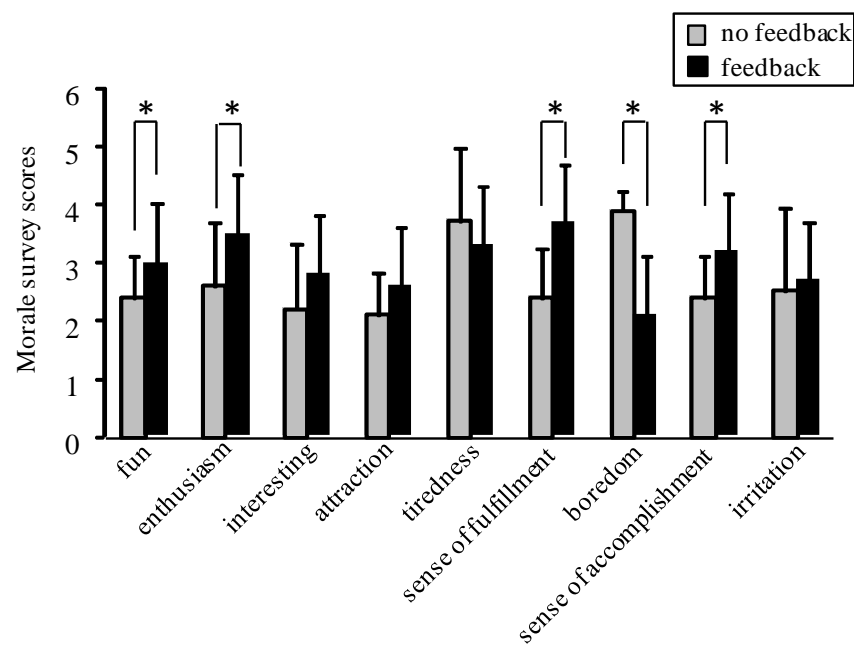

Fig. 5 Morale survey scores during assembly work with and without feedback information (mean value $\pm \mathrm{SD}, * p<0.05$ ).

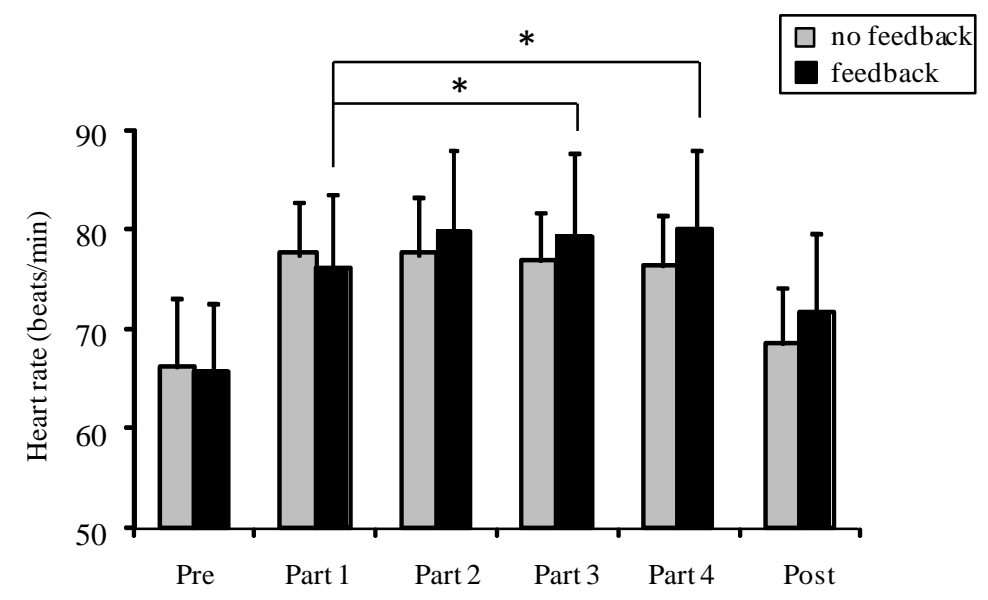

Fig. 6 Changes of heart rate during assembly work with and without feedback information (mean value $\pm \mathrm{SD}$, * $p<0.05$ ).

\section{$3 \cdot 3$ 心電図}

図 6 に作業中の心拍数の結果を示す. 分散分析の結果，期間に主効果が $(F(5,45)=58.54 ; p<0.01)$, 作業条 件と期間の間に交互作用があった $(\mathrm{F}(5,45)=6.53 ; \mathrm{p}<0.01)$. 両条件共に安静時に比べ作業中の心拍数が有意 に高かった．また，作業情報無では作業時の心拍数が概ね横ばいであったが，作業情報有では， 3 期， 4 期の心拍 数が 1 期の心拍数と比べて有意に高かった。 心拍変動の LF 成分，HF 成分， LF/HFにおいてはいずれにおいて も作業条件間に有意差は認められなかった。

\section{$3 \cdot 4$ 脳波}

$\theta$ 波は，T6において，作業条件に主効果があり（F（1.9）=6.88; $<<0.05 ）$ ，作業情報無が作業情報有に比べ有 意に高かった。しかし，その他の部位においては統計的な有意差はみられなかった．図 7 と図 8 に組立作業時に おける $\alpha 1$ 波と $\alpha 2$ 波の変化を示寸， $\alpha 1$ 波は，F4（F（1.9）=8.89； p <0.05），Fz（F（1.9）=6.21； p <0.05）部 位において作業条件に主効果があり，作業情報有が作業情報無に比べ有意に高かった．また， $\alpha 1$ 波は F3（F（3.27） $=3.35 ; \mathrm{p}<0.05)$, F8 $(\mathrm{F}(3.27)=3.04 ; \mathrm{p}<0.05), \mathrm{C} 3(\mathrm{~F}(3.27)=3.06 ; \mathrm{p}<0.05), \mathrm{C} 4(\mathrm{~F}(3.27)=3.27 ; \mathrm{p}<0.05)$, $\mathrm{Cz}(\mathrm{F}(3.27)=4.82 ; \mathrm{p}<0.01), \mathrm{P} 4(\mathrm{~F}(3.27)=3.06 ; \mathrm{p}<0.05), \mathrm{Pz}(\mathrm{F}(3.27)=4.32 ; \mathrm{p}<0.05)$ 部位において交 
F3

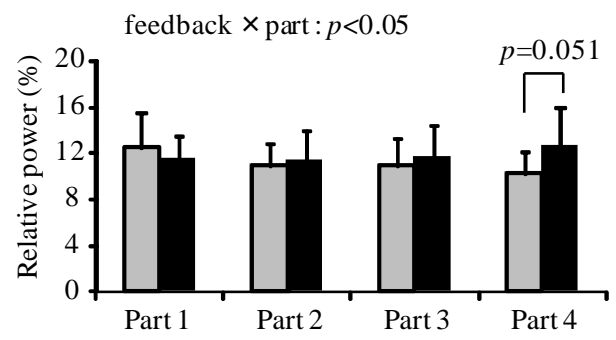

C3

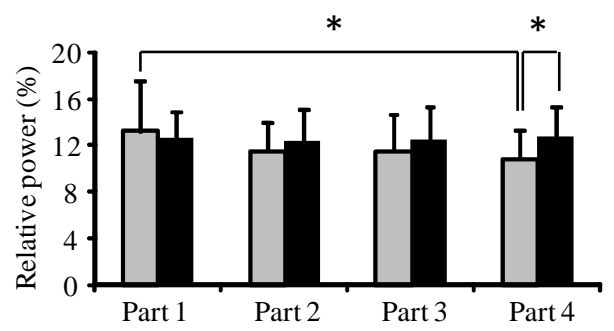

$\mathrm{Fz}$

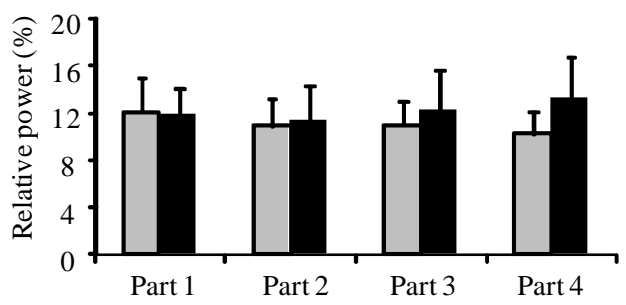

feedback $\times$ part : $p<0.05$

$\mathrm{Pz}$

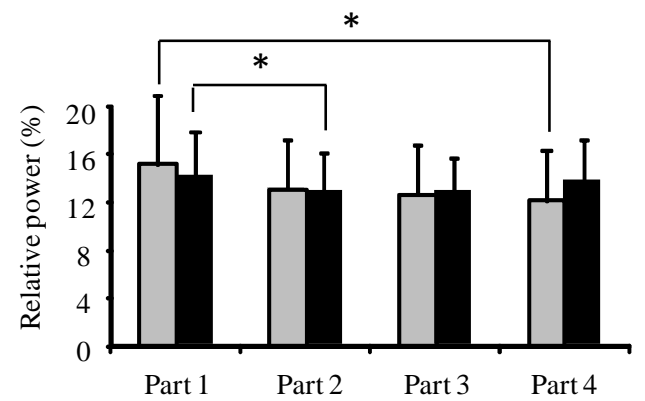

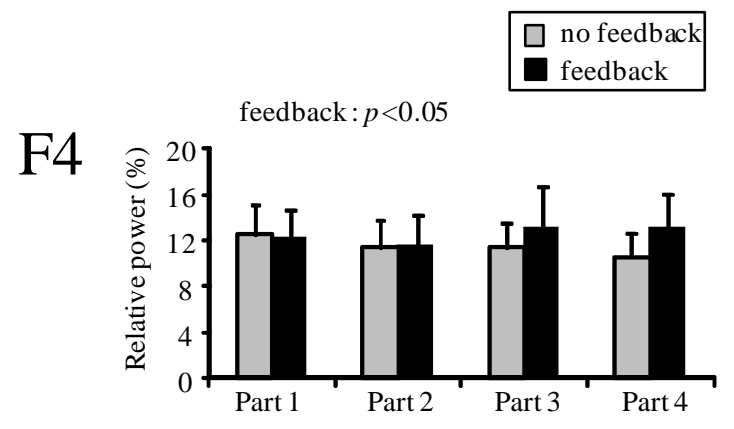

$\mathrm{C} 4$

feedback $\times$ part : $p<0.05$

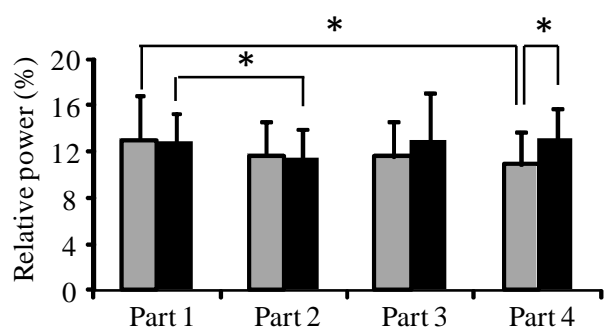

$\mathrm{Cz}$

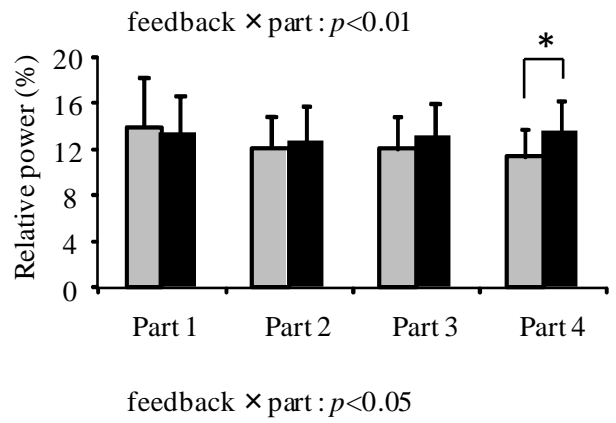

P4

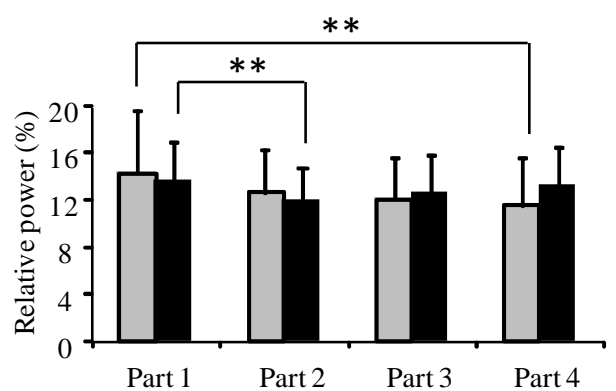

Fig. 7 EEG alpha $1(8 \sim 10 \mathrm{~Hz})$ waves in each area during assembly work with and without feedback information (mean value $\pm \mathrm{SD} ; * p<0.05$ ).

互作用が確認された．F3 では 4 期において作業情報有が作業情報無に比べ $\alpha 1$ 波が高い傾向を示した．F8では 2 期において作業情報無が作業情報有に比べて $\alpha 1$ 波が有意に高かった. C 3 では作業情報無で 4 期が 1 期より $\alpha 1$ 波が有意に低下し， 4 期では作業情報有が作業情報無に比べ $\alpha 1$ 波が有意に高かった．C4 では，作業情報無で 4 期が 1 期より，作業情報有では 2 期が 1 期より $\alpha 1$ 波が有意に低下し， 4 期では作業情報有が作業情報無より有意 に高かった. $\mathrm{Cz}$ では，4期において作業情報有が作業情報無より $\alpha 1$ 波が有意に高かった. その他, $\mathrm{P} 4, \mathrm{Pz}$ では, 作業情報無で 4 期が 1 期より，作業情報有では 2 期が 1 期より有意に低下した。 また，P3 （F（1.9）=6.522； p $<0.01 ）, \mathrm{~T} 5 （ \mathrm{~F} （ 1.9 ）=6.189 ; \mathrm{p}<0.01 ）$ 部位では期間に主効果があり，P3 では 4 期が 1 期より $\alpha 1$ 波が有意に 低下し， T5 では 3 期が 1 期より $\alpha 1$ 波が有意に低下した。 $\alpha 2$ 波は F3（F（1.9）=6.080； p < 0.05）において，作 業条件に主効果が確認され，作業情報有が作業情報無より有意に高かった．また，F4，Fz，Cz 部位においても作 業情報有が作業情報無より $\alpha 2$ 波が高い傾向を示した。しかし，その他の部位においては統計的な有意差はみら 
F3

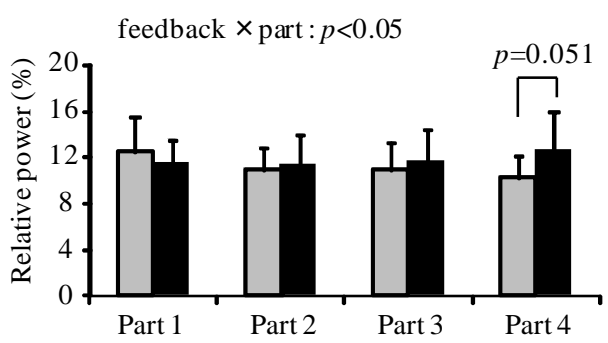

$\mathrm{C} 3$

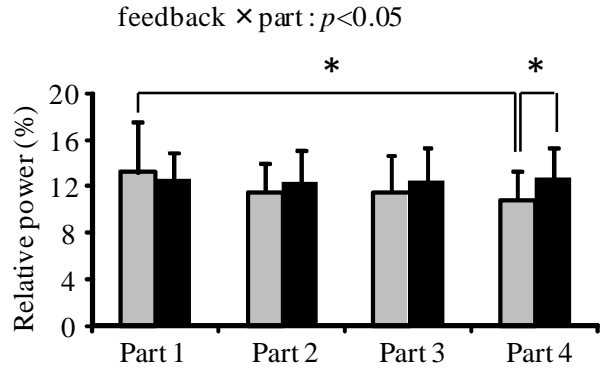

$\mathrm{Fz}$

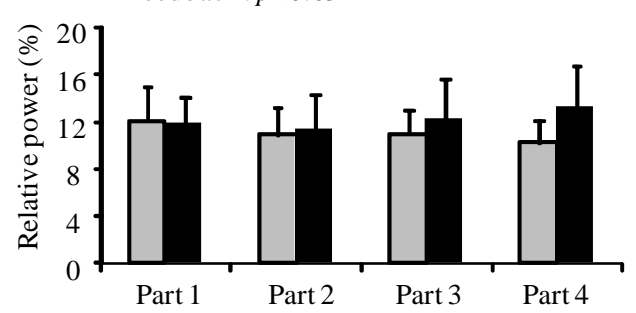

F4

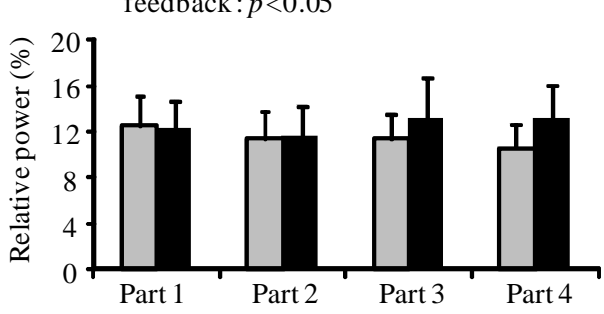

$\mathrm{C} 4$

feedback $\times$ part : $p<0.05$

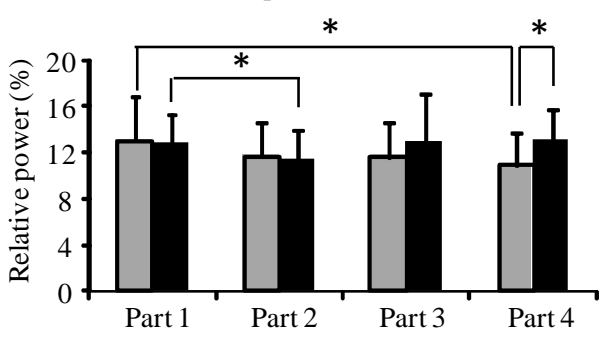

$\mathrm{Cz}$

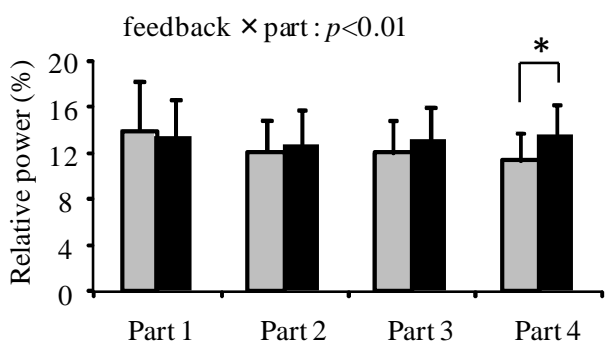

Fig. 8 EEG alpha 2(10 13Hz) waves in each area during assembly work with and without feedback information (mean value $\pm \mathrm{SD}$ ).

れなかった～$\beta 2$ 波は $\mathrm{Cz} （ \mathrm{~F} （ 1.9 ）=6.699 ; \mathrm{p}<0.01), \mathrm{Pz}(\mathrm{F} （ 1.9 ）=3.534 ; \mathrm{p}<0.05 ）$ において期間に主効果があ り， 1 期より 2 期が有意に高かった.

\section{4. 考察}

本研究は，作業情報をフィードバックし，職務充実を図った際の作業者の脳波計測により，脳内活動領野の観 点から職務充実の効果を考察することを目的とした，その結果，作業情報のフィードバックなしで同じ作業を繰 り返すよりも作業者に作業進行度や不良情報をフィードバックすることで，作業者はだるさや退屈感，不満が減 少し, 充実感や能力発揮感, 熱中, 楽しいなど作業意欲が向上した. 長町 ${ }^{(21)}$ は仕事とモチベーションとの関係に おいて重要な働きをする心理的要因として能力発揮, 自己成長を挙げている. 本研究においても作業情報のフィ 一ドバックが作業者自身で PDCA サイクルを回すことを促進し，それにより作業者の能力発揮感と作業意欲の向 上につながったと考えられる．このような作業意欲の向上は作業パフォーマンスに反映され，作業情報有は作業 情報無より組立にかかるサイクルタイムが短くなって生産性が有意に向上した．作業情報のフィードバックによ る作業成績の向上は多岐の分野において検証されている．川上 ${ }^{(22)}$ は作業の時間規制要因を排除し，作業情報を提 示した場合, 生産性が向上し, 作業者が作業に対して積極的になったと報告している.また, Schmidt ${ }^{(23)}$ は運動 学習課題を行う際に正しいフィードバック情報を与えることによって課題成績が向上したと述心゙, 福田ら ${ }^{(24)}$ と Jung ら ${ }^{(25)}$ は視覚的にフィードバック寸ることにより最大随意収縮における発揮筋力が増大したと報告している. 本研究の結果はこれらの先行研究と一致するといえる. 
ところで，川村 ${ }^{(17)}$ は，扁桃核は情動機構の発現に皮質下レベルで関わると同時に、大脳皮質一扁桃核間の神経 回路が働くことによって，賞罰，報酬などの意味付け、動機付けなどの形成がなされると報告している．また， Goldman-Rakic ら $^{(26)}$ は扁桃体や海馬からの情動・認知・記憶・価值判断に関する情報が前頭前野へ入力されるこ とによって皮質が活性化され、ワーキングメモリーが適正に実行されると報告している．これらは人の情動や動 機付け，注意などが前頭葉と深く関わることを示し，本実験のように作業者に情報のフィードバックをして作業

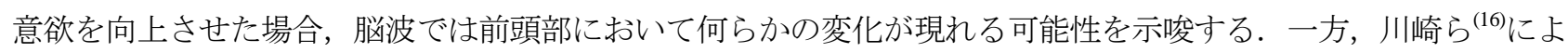
ると, 前頭部での $\alpha 1$ 波の増加は楽しさの推定に関係し, 前頭部から後頭部にかけての中心部 $\alpha 2$ 波の増加は達成 感の推定に関連すると報告している。また，松永ら ${ }^{(27)}$ は前頭部の $\alpha$ 波と主観的な満足感の間には正の相関がある と報告している，本研究では，退屈感と不満が高かった作業情報無では，作業序盤に比べ作業終盤に行くほど前 頭部・中心部・頭頂部において $\alpha 1$ 波が有意に低下した。これに対して充実感や能力発揮感が高かった作業情報 有では作業終盤の 4 期において, 前頭部と中心部である F3，F4，Fz，C3，C4，Cz 部位で作業情報無より $\alpha 1$ 波 が有意に高くなった．また，作業情報有は作業全般において作業情報無に比べ F3，F4，Fz，Cz 部位で $\alpha 2$ 波が高 い傾向を示した．このように作業意欲の向上時における作業者の前頭部・中心部の $\alpha 1$ 波と $\alpha 2$ 波の増加は，情動 や動機付けが前頭部の脳活動と関連するという先行研究や川崎らと松永らの研究結果と一致する.これは脳波計 測が職務充実の効果, つまり作業者の仕事への楽しさ, 達成感, 満足感など作業意欲の向上状態の評価に有効な 指標となる可能性を示唆する.

一方で，作業意欲の向上は心電図の結果においても現れた．作業情報をフィードバックした時，作業者の作業 への意欲が高まることにより交感神経活動が活発になり，作業序盤に比べ作業終盤において心拍数の有意な増加 がみられた. しかし，作業時における心拍数の増加は作業者の生体負担を高める可能性がある. 本実験は 50 分程 度の作業で 28 台という限られた目標台数を組み立てるものであった. そのため, 作業者に作業情報をフィードバ ックする場合，作業者は作業終盤にいくほど時間圧迫感を感じる可能性が考えられる．これは，作業情報有が作

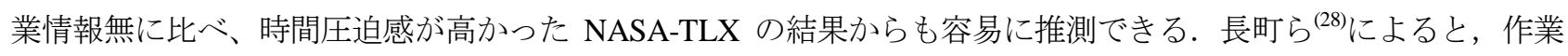
意欲が高い場合作業時の心拍数が増加するが, 時間経過とともに心拍数は作業開始時に近づいたと報告している. 従って, 作業時間が長時間（1 日 8 時間業務）になると, 高まった心拍数が作業開始時に戻ると考えられる. ま た，グループの目標台数に対してフィードバックすると個人への圧力が小さくなるため, 心拍数増加に対する䀣 念は解消されると考えられる. 本研究では心拍数では作業条件間に差がみられたが，心拍変動においては有意差 が認められなかった．これはメンタルワークロードによる自律神経活動の変化を心拍変動で捉える場合，呼吸の 影響を排除するために呼吸統制が必要である(29). しかし, 本研究では 50 分弱の組立作業であったため, 作業者 への負担を考慮し呼吸統制を行わなかったことが原因であると考えられる.

以上のことより，作業情報を作業者にフィードバックする職務充実を図ることにより，作業意欲が高まり，生 産性も向上した. また, 楽しさ, 達成感, 満足感と関連する前頭部, 中心部の $\alpha 1$ 波, $\alpha 2$ 波が有意に増加したこ とから, 脳活動計測よりハーズバーグの動機づけ要因を網羅する職務充実の効果を確認する事ができた.

\section{5. 結論}

本研究では作業情報をフィードバックし, 職務充実を図った時の作業者の脳波計測により, 脳内活動領野の観 点から職務充実の効果を考察した。得られた成果を要約し, 次の 2 点をまとめとする.

1）作業情報をフィードバックする職務充実を図ることにより, 作業者の作業意欲が高まり, 生産性が向上した.

2）作業者に作業情報をフィードバックすることで楽しさ, 達成感, 満足感と関連する前頭部, 中心部の $\alpha 1$ 波, $\alpha 2$ 波が有意に増加し, 職務充実の効果が脳活動計測からも確認できた.

\section{文献}

(1) Velkoborsky V.G, “科学的管理法の最近の傾向”, 日本機械学會誌, Vol. 54, No. 391(1951), p 300.

（2）八巻直躬，“自主管理方式と科学的管理法” 日本経営工学会誌，Vol.32， No. 5(1981), pp. 313-322.

（3）長町三生，働きがいを生むシステム職務充実の設計，（1973），pp. 18-19，ダイヤモンド社. 
(4) F. ハーズバーグ，北野利信訳，仕事と人間性，(1968)，pp．83-90，東洋経済新聞社.

（5）村杉健，大橋岩雄，五百蔵隆治，“層別比較を中心とした動機付け衛星理論の吟味一ハーズバーグの M-H理論 の実証的研究（第1報）”, 日本経営工学会誌, Vol. 25, No. 3 (1974), pp. 227-232 .

(6) 村杉健, 大橋岩雄, 五百蔵隆治, “モラール・サーベイに関連した動機付け衛星理論の吟味一ハーズバーグの M-H理論の実証的研究（第2報）”, 日本経営工学会誌, Vol. 25, No. 4(1975), pp. 227-232.

(7) 村杉健, 大橋岩雄, 五百蔵隆治, “生きがいや疎外と関連した動機付け衛星理論の吟味一ハーズバーグのM-H 理論の実証的研究（第3報）”，日本経営工学会誌，Vol. 27，No. 1(1976)，pp. 63-68.

（8）村杉健，大橋岩雄，五百蔵隆治，“動機付け衛生理論の対人関係因子一ハーズバーグの $\mathrm{M}-\mathrm{H}$ 理論の実証的研究 (第 5 報)”， 日本経営工学会誌，Vol. 33，No．2 (1982)，pp. 148-153.

(9) 川上満幸, 丹下敏, “二つの異なる組立システムの実験的比較・検討 - 量産型組立作業システムの設計に関する 研究”, 日本経営工学会誌, Vol. 31, No. 2 (1980), pp. 181-187.

（10）川上満幸，上野俊夫，“組立作業における取り置き作業の生産性への影響 - 量産型組立作業システムの設計に関 する研究”, 日本経営工学会誌, Vol. 36, No. 4 (1985), pp. 275-280.

(11) 西野達夫, 正戸茂, “職務設計における遊び的要素の活用についての実験的研究”, 日本経営工学会誌, Vol. 31, No. 4 (1981), pp. 411-417.

(12) 矢田博, 藤田晃, “「自主管理システム」の提案とその検証 - 現業部門における「自主管理システム」に関する 研究(第 1 報)” 日本経営工学会誌, Vol. 27, No. 4 (1977), pp. 384-390.

(13) 安藤博, “やる気を高める賃金, 賞与, 労働時間の決め方は”, 人手不足を乗り切る事典, 工場管理 1991 年 9 月 臨時増刊号, pp. 224-225.

（14）矢田博，藤田晃，“「自主管理システム」の提案とその検証 - 現業部門における「自主管理システム」に関する 研究(第 2 報)”, 日本経営工学会誌, Vol. 30, No. 1(1979), pp. 65-71.

（15）長町三生，“企業における小集団活動とその活性化の原理”，日本経営工学会誌，Vol．30，No３ (1979), pp. 185-192.

（16）川崎 真弘，甲斐田 幸佐，岸 浩司，渡部 生聖，山田 整，山口 陽子，“シータ波とアルファ波を用いた運転技 能の向上に伴う喜びと満足度の推定” 人間工学会誌，Vol. 46， No. 5(2010), pp. 307-316.

(17) 川村光毅, “扁桃体の構成と機能”、臨床精神医学, Vol. 36 (2007), pp. 817-828.

(18) Yoshida, T. and Iwaki, T., "The study of early emotion processing in the frontal area using a two-dipole source model, Japanese Psychological Research Vol. 42 (2000) pp 54-68

(19) 川上満幸，上野俊夫，“部品の種類数と点数からみた最適作業量に関寸る研究”，日本経営工学会誌，Vol. 40, No. 6 (1990), pp. 421-426.

(20) 三宅晋司, 神代雅晴, “メンタルワークロードの主観的評価法 NASA-TLX と SWAT の紹介および簡便法の提案”, 人間工学会誌, Vol. 29, No. 6(1993), pp. 399-408.

(21) 長町三生, “ジョブデザインとモチベーション”，日本経営工学会誌，Vol. 26， No. 4(1976), pp. 302-307.

(22) 川上満幸, “作業集約方式の構成要因に関する実験的考察一量産型組立作業システムの設計に関する研究”, 日本 経営工学会誌, Vol. 36, No. 2 (1985), pp. 133-138.

(23) Schmidt, R. A, Motor Control andLearning: A Behavioral Emphasis (1988), Human Kinetics Publishers, Illinois.

（24）福田誠，赤木亮太，金久博昭，川上泰雄，福永哲夫，“視覚フィードバックを伴う最大随意収縮が筋活動 および筋横断面積あたりの筋力に及ぼす影響”，スポーツ科学研究，Vol. 6(2009)， pp. 17-29.

(25) Jung, M. C., Hallbeck, M. S., "Quantification of the effects of instruction type, verbal encouragement, and visual feedback on static and peak handgrip strength", International Journal of Industrial Ergonomics, Vol. 34, No. 5 (2004), pp. 367-374.

(26) Goldman-Rakic P. S., Selemon, L. D., Schwartz, M. L., "Dual pathways connecting the dorsolateral prefrontal cortex with the hippocampal formation and parahippocampal cortex in the rhesus monkey", Neurosci, Vol. 12 (1984), pp. 719-743.

（27）松永 久，中沢 弘，“満足感計測のための基礎的研究”, 人間工学会誌，Vol. 34, No. 4 (1999), pp. 191-200. (28) 長町三生，榎本悟朗，厚坊克俊，“職務設計の実験的研究”, 人間工学会誌， Vol. 11， No. 1 (1975), pp. 1-8. （29）芳賀繁，メンタルワークロードの理論と測定 (2001)， pp. 19-22，日本出版サービス（株）. 